\title{
The use of indonesian soybean variety with time and planting location to the production to meet the demand
}

\author{
Nelly Budiharti ${ }^{1 . *}$ and Ing Wardana ${ }^{2}$ \\ ${ }^{1}$ Industrial Enginering Department, National Institute of Technology, 65145 Malang, Indonesia, \\ ${ }^{2}$ Mechanical Engineering Department, Brawijaya University, 65145 Malang, Indonesia
}

\begin{abstract}
Based on data from the Central Bureau of Statistics, Jakarta [1] , Ministry of Agriculture and Preliminary Study of National Medium-Term Development Plan (RPJMN) on food and agriculture, stage III, 2015-2019 [2] the demand for soybeans in Indonesia will remain increasing by the population growth. The author's research [3] previously concluded that efforts to increase the number of Indonesian soybean production include utilizing abandoned land and planting throughout the year. This study acts as a verification of previous research by using planting of Indonesian varieties of soybean in various time and planting location in order to meet the demand for soybean commodity. This research was conducted by experiment using 3 superior varieties with 3 planting time, which is planted in $3 \mathrm{sub}$ districts of Malang regency, East Java province, Indonesia. Data Processing and analysis use experimental design that is latin square design with $95 \%$ confidence level. The results obtained that the use of different varieties with different planting time and location has no effect on the production. The different production result is on account of the fact that each variety has its own profile.
\end{abstract}

\section{Introduction}

The need for Soybeans will increase from 2 million tons in 2008 to about 2.6 million tons by $2020[3,4]$. As shown in Figure 1. below:

*Corresponding author: budiharti1309@gmail.com 


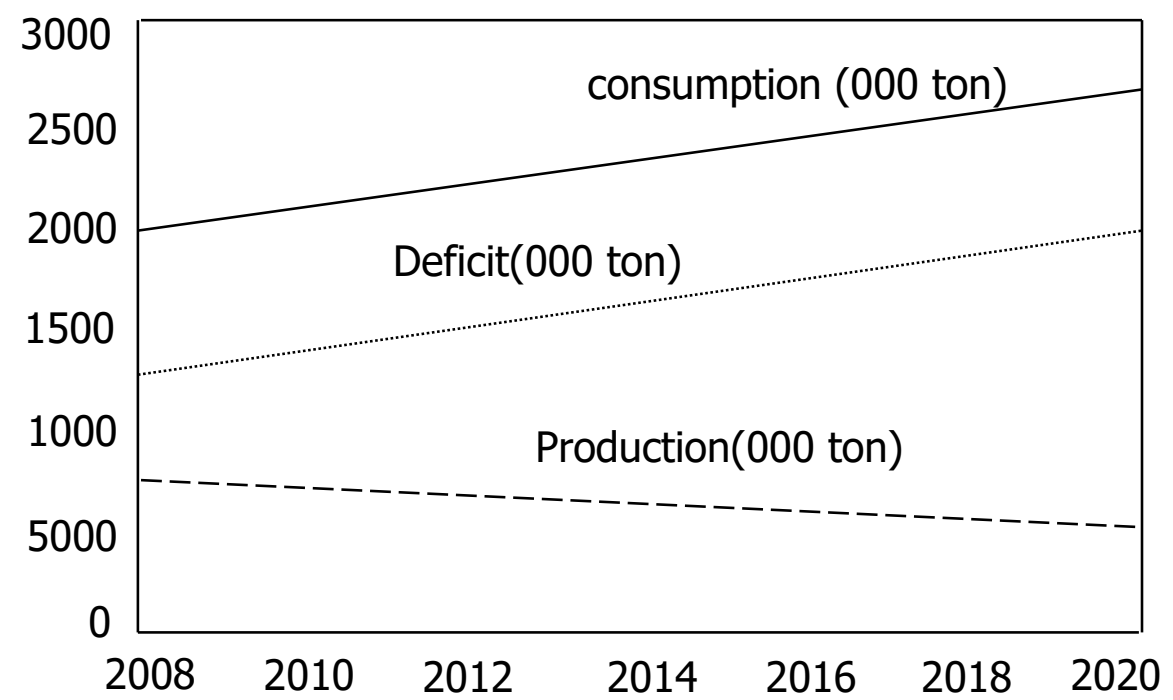

Fig. 1. The Projection of soybean production and deficit in Indonesia 2008-2020 on the assumption of no policy responded by farmers [4]

If the soybean production enlargement program were not responded by farmers, the national soybean production would continue to decline [4].

One of experts in the field of soybean farming, Suyono, who was also a lecturer at the Faculty of Agriculture of Jember University, said that domestic soybean production should be improved to meet the needs [5].

Thus far, Indonesian soybean farmers have planted rice based on the availability of soybean seedlings in their respective areas. It is due to the limitations of breeder seeds. In fact, the number of varieties that have been already found by breeders has been quite a lot $[6,7,8,9,10,11]$. The time of soybean planting, each region has different planting times, such as in Ngawi District planting season from February to May [12,13], in Jember Regency in June / July, Banyuwangi District in June and December [9]. Likewise for planting sites, there was unsuitable soil for soybean and the use of improved varieties that were possible with the type of land $[9,10]$, and planting times that needed to be adapted to the pattern of cultivation of local farmers $(4,8]$. Seed factor is what determines the level of soybean yield, so it needs to be considered seriously, because soybean seed demand is so much; for consumption and industry [14,15.16]

Therefore, research needed to be done to determine whether the use of superior varieties with time and location of planting will affect the production.

\section{Research Methods}

This study was conducted with experiments due to the evidence of the statements that have been included in the introduction. The experiment was conducted by using 3 independent variables with each indicator that is Soybean Varieties of Indonesia with indicator of 3 superior varieties applied in Pakis Haji Subdistrict, Tumpang District and Singosari Subdistrict, Malang Regency, East Java Province, Indonesia as variable of planting location and variable of planting time ie January, February and March. Processing and data analysis using Latin Square Experimental Design with Random Models, in accordance with the guidance of the experimental design grand theory [17]. Design of Cage Square Experiment is a treatment that uses at least 3 independent variables but the analysis and decision taken 
only for 1 independent variable is considered more important. The word square because the data table treatment form a square. The Latin word is a naming that denotes the use of Latin letters in the treatment data table. The Random Model is a naming that shows that the conclusions taken not only for the experimental results of the free variables conducted (in this study are 3 varieties of Indonesian soybean) but applies also to all varieties of Indonesian soybeans that have been glorified / found throughout Indonesia.

\section{Result and discussion}

This research was conducted by experimenting planting of soybean varieties of Indonesia, with reference and guidance of Indonesian Soybean Cultivation from soybean research and development unit, agriculture department especially food crops, Jember Regency, East Java Province, Indonesia [18].

After planting with reference from [18], with the cultivation process, then the crop is recorded for each variety planted in 3 locations with 3 time planting.

Here are the results of the production of 3 varieties of soybean Indonesia with 3 Time and 3 Locations Plant as follows:

Table 1. The production of 3 Indonesian Soybean Varieties with Planting Time and Locations

\begin{tabular}{|c|c|c|c|c|c|}
\hline \multirow{2}{*}{$\begin{array}{c}\text { Planting } \\
\text { time }\end{array}$} & \multicolumn{3}{|c|}{ Planting location } & & \\
\cline { 2 - 6 } & Pakis Haji & Tumpang & Singosari & Sum & Mean \\
\hline January & $\begin{array}{c}\text { Dena1 } \\
(2,7)\end{array}$ & $\begin{array}{c}\text { Dega1 } \\
(3,4)\end{array}$ & $\begin{array}{c}\text { Grobogan } \\
(3,1)\end{array}$ & 9,2 & 3,07 \\
\hline February & $\begin{array}{c}\text { Dega1 } \\
(3,01)\end{array}$ & $\begin{array}{c}\text { Grobogan } \\
(2,9)\end{array}$ & $\begin{array}{c}\text { Dena1 } \\
(2,6)\end{array}$ & 8,5 & 2,83 \\
\hline March & $\begin{array}{c}\text { Grobogan } \\
(3,2)\end{array}$ & $\begin{array}{c}\text { Dena1 } \\
(2,4)\end{array}$ & $\begin{array}{c}\text { Degal } \\
(3,3)\end{array}$ & 8,9 & 3,0 \\
\hline Sum & 8,9 & 8,7 & 9 & 26,6 & - \\
\hline Mean & 3 & 2,9 & 3,0 & - & \\
\hline
\end{tabular}

Hypothesis: Variance $(\sigma 2)=0$, ie: The hypothesis of this study is that there is no difference in yield / production for each soybean varieties of Indonesia. They are planted in different locations and different planting times. Each variety has its own profile, in accordance with the results of breeding obtained.

\subsection{Data processing are as follow:}

$$
\begin{gathered}
4 \quad \sum \mathrm{Y}^{2}=(2,7)^{2}+(3,01)^{2}+\ldots+(2,6)^{2}+(3,3)^{2}=79,58 \\
5 \quad \mathrm{Ry}=(26,6)^{2} / 3=78,62 \\
6 \quad \mathrm{By}=(9,2)^{2}+(8,5)^{2}+(8,9)^{2} / 3-78,62=2,08 \\
7 \quad \mathrm{Ky}=(8,9)^{2}+(8,7)^{2}+(9)^{2} / 3-78,62=0,01 \\
8 \quad \text { JDena1 }=2,7+2,4+2,6=7,7 \\
9 \quad \text { JDega1 }=3,01+3,4+3,3=9,7 \\
10 \quad \text { JGrobogan }=3,2+2,9+3,1=9,2 \\
11 \quad \mathrm{Py}=(7,7)^{2}+(9,7)^{2}+(9,2)^{2} / 3-78,62=0,78 \\
12 \quad \mathrm{Ey}=79,58-78,62-2,08-0,01-0,78=-1,91
\end{gathered}
$$




\subsection{Data Analysis}

From the results of data processing can be obtained anava table which then taken the decision to accept or reject the hypothesis.

Table 2. Variant Analysis of 3 Indonesian soybean Variety

\begin{tabular}{|c|c|c|c|c|}
\hline Source of variation & $\begin{array}{c}\text { Sum Squares } \\
\text { (SS) }\end{array}$ & $\begin{array}{c}\text { Mean squares } \\
(\mathrm{MS})\end{array}$ & $\begin{array}{c}\text { Mean squares } \\
(\mathrm{MS})\end{array}$ & F Calculate \\
\hline Mean & 1 & 78,62 & 78,62 & \\
Planting time & 2 & 2,08 & 1,04 & \\
Planting location & 2 & 0,01 & 0,005 & \\
Varieties & 2 & 0,78 & 0,39 & 0,41 \\
Significance Level & 2 & $-1,91$ & $-0,955$ & \\
\hline
\end{tabular}

With the confidence level of $95 \%$, the F value was $0,05(2,2)=19 \rightarrow$ with F calculate $<$ F table; the hypothesis was confirmed. It meant that there was no difference in the production due to the varieties with time and location of planting. The production of each of the variety accorded with its respective profiles. The production profiles of each variety are as follows (Source: UPTD (Technical Implementation Unit of the Service), Bangsal sari Jember, BATAN (the National Nuclear Energy Agency) Bandung and Balitkabi (Research Institute for Beans and Tubers) Malang, East Java Province, Indonesia): (in Ton/ha)

1. Dega 1 : Potential yield was $2,78-3,82$

2. Dena1 : Potential yield was $1,7-2,9$

3. Grobogan : Potential yield was $2,77-3,4$

\section{Conclusion}

1. The selection of Indonesian soybean variety with the planting time and location did not affect the crop result

2. Indonesian soybean variety has its own profiles on production potency.

3. The farmers selected the variety not based solely upon the production yield but on consideration of compatibility in its use according to the farmer.

4. The Novelty of this research is finding Indonesia soybean varieties that can be planted in various field and various planting time

\section{References}

1. Badan Pusat Statistik, Perkembangan Beberapa Indikator Utama Sosial Ekonomi Indonesia, (Jakarta, Katalog BPS 3101015, (2013)

2. Central Bureau of Statistics, Jakarta. (2013)

3. Direktorat Pangan dan Pertanian, Studi Pendahuluan Rencana Pembangunan Jangka Menengah Nasional (RPJMN) Bidang Pangan dan Pertanian 2015-2019 Kementerian Perencanaan Pembangunan Nasional, Badan Perencanaan Pembangunan Nasional, 2013 
4. Directorate of Food and Agriculture, Preliminary Study of National Medium Term Development Plan (RPJMN) for Food and Agriculture 2015-2019, Ministry of National Development Planning, National Development Planning Agency (2013)

5. B. Nelly, Praktikto, S. Soedjito and B. S. Purnomo, Journal of Engineering Science and Technology (JESTEC) (2017)

6. A. Harsono, IPTEK Tanaman Pangan, (2008)

7. A. Harsono, Science of Food, 3, 2, 2008)

8. Suyono, Tawarkan Solusi Untuk Swasembada Kedelai, www.uhej.ac.id/berita/akademik2013 (2013)

9. Suyono, Offering a solution for Soybean Self-suffiency supply (2013)

10. Direktorat Jendral Tanaman Pangan, Kementan (2010)

11. Directorate General of Food Crops, The Ministry of agriculture (2010)

12. Heriyanto, Jurnal Cakrawala, 6 (2012)

13. Heriyanto, Jurnal Cakrawala 6 (2012)

14. Sinar Tani, Pengembangan Kedelai di Kawasan Hutan Sebagai Sumber Benih, Agroinovasi, 15(3740), Balitbang pertanian (2013)

15. Sinar Tani, Soybean Devplovement in Forest for Breeder Supply, Agroinovasi, 15(3740), Balitbang pertanian (2013)

16. Balitkabi, Deskripsi Varietas Unggul Kacang-kacangan dan Umbi-umbian.Balai Penelitian Kacang-kacangan dan Umbi-umbian (Malang, Balitkabi, 2010)

17. Balitkabi. 2010. Description of Superior Varieties of Beans and Tubers. Research Institute for Pulses and Tubers, Balitkabi, Malang.

18. M. N. Ishaq and B. O. Ehirim, World Journal of Agricultural Sciences 2 (2014)

19. F.S.C. Hassan, B. Fakheri, and A. Sattari, International Journal of Agriculture and Crop Sciences (IJACS) 7 (2014)

20. A. M. Fagi, F. A. Bahar, and J. Budianto, Sumbangan Pemikiran Bagi Penentuan Kebijakan Peningkatan produksi Kedelai, IPTEK Tanaman Fisher dan Schomberg. 2006 dalam Susilowati, S.H., dkk. 2010. Indikator Pembangunan Pertanian dan Pedesaan. Pusat Penelitian dan Pengebangan Pertanian Departemen Pertanian Pangan, 4, 2 (2009)

21. A. M. Fagi, F. A. Bahar, and J. Budianto, Contribution for the determination of soybean production policy, Plant Science of Fisher dan Schomberg, 2006 in Susilowati, et al, 2010, Agricultural and rural development indicators, Center for research and development of food agriculture department, 4, 2 (2009)

22. B. Nelly, Praktikto, S. Soedjito and B. S. Purnomo, Journal Agricultural and Biological Science (JABS) 11 (2016)

23. M. H. I. Nur, Pengkajian Pemetaan Kebutuhan Benih Padi, Jagung, Kedelai Dan Pengembangan Penangkaran Benih Yang Efisien (2010)

24. Assesment and Mapping of The Requirement of Rice, Comand Soybean Seeds and The Development of Effisiency Seed Breeding

25. J. M. Mahasi, J. Mukalama, R. C. Mursoy, P. Mbehero and A. B. Vanluwe, A Crop Science Conference Proceedings 10 (2011)

26. B. Nelly B, Putu, Sonny, Jurnal PASTI Volume XI No 2 (2017)

27. B. Nelly B, Putu, Sonny, Jurnal PASTI Volume XI No 2 (2017)

28. Suwanda, ALFABETA (2017) 
29. Suwanda, ALFABETA (2017)

30. D. Sumianto, Diklat Teknis Agribisnis, Balai Pusat Pelatihan dan Pengembangan ( BPPP ), KETINDAN, Lawang, Jawa Timur (2015)

31. D. Sumianto, BBPP (Agricultural Training Center) Ketindan, Soybean Agriculture business Technical Training, the production of the experiment done are as follow (2015) 